\title{
Hubungan antara Preeklampsia Berat Awitan Dini dengan Pertumbuhan Janina Terhambat pada Pasien Preeklamsia Beratdi RSUP Dr. Sardjito Yogyakarta
}

\author{
Miftakhul Muslichah¹, Shinta Prawitasari², Irwan Taufiqur Rachman ${ }^{3}$ \\ 1,2,3 Departemen Obstetri dan Ginekologi \\ Fakultas Kedokteran, Kesehatan Masyarakat dan Keperawatan \\ Universitas Gadjah Mada \\ Korespondensi: miftaquw@gmail.com
}

Submisi: 17 September 2020; Revisi: 12 Oktober 2020; Penerimaan: 15 Oktober 2020

\begin{abstract}
Background: Intrauterine Growth Restriction (IUGR) is a fetal complication that often occurs in patients with severe preeclampsia and eclampsia. The incidence of early onset of severe preeclampsia ranged 5-20\% of all preeclampsia cases that related to morbidity and mortality of neonatal, the incidence of IUGR was 3-7\%, while advanced onset severe preeclampsia was $75-80 \%$ of all preeclampsia cases that related to morbidity maternal. Objective: To investigate the relationship between early onset severe preeclampsia and IUGR in Sardjito Hospital Yogyakarta.

Method: Study design was cross sectional study. The population were patients identified with preeclampsia with single fetus in RSUP DR Sardjito Yogyakarta from 2013 to 2015 . The samples were patients with severe preeclampsia (135 subjects); early onset preeclampsia 105 subcjects and late onset preeclampsia 30 subjects. IUGR prevalence by early onset-late onset preeclampsia was evaluated using Chi Square test. Mantel-haenszel stratification used to evaluate confounding factor. Multivariable used logistic regression.

Result and Discussion: Early onset preeclampsia were 51 subjects (48.57\%) with IUGR while late onset were 7 subjects (23.33\%). Subjects identified with early onset preeclampsia and genuine preeclampsia have the highest prevalence of IUGR RP (CI 95\%)=2.453 (1.170-5.141) and $p=0,007$. IUGR prevalence in subjects with early onset preeclampsia OR $(C \mid 95 \%)=3,257(1.244-8.530)$ and $p=0.016$; age OR $(C l$ 95\%)=0.488 $(0.202-1.178)$ and $\mathrm{p}=0.111$; parity $\mathrm{OR}(\mathrm{Cl} 95 \%)=1.159(0.461-2.912)$ and $\mathrm{p}=0.111$; type of PE OR $(\mathrm{Cl} 95 \%)=0.730(0.294-1.814)$ and $p=0.498$; and proteinuria degree OR (CI 95\%) $=0.955(0.464-1.968)$ and $\mathrm{p}=0.901$.

Conclusion: Severe preeeclampsia with early onset preeclampsia is associated significantly with IUGR.
\end{abstract}

Keywords: Severe preeclampsia; early onset preeclampsia; late onset preeclampsia, IUGR

\section{ABSTRAK}

Latar Belakang: Pertumbuhan Janin Terhambat (PJT) merupakan salah satu komplikasi janin yang sering terjadi pada pasien Preeklamsia Berat (PEB) dan eklamsia. Angka kejadian PEB awitan dini berkisar 5-20\% dari keseluruhan kasus preeklamsia yang berhubungan dengan neonatal morbiditas dan mortalitas, dimana angka kejadian PJT sendiri berkisar 3-7\%, sedangkan angka kejadian PEB awitan lanjut sebesar 75-80\% dari keseluruhan kasus preeklamsia yang berhubungan dengan maternal morbiditas.

Tujuan: Untuk mengetahui hubungan antara PEB awitan dini dan kejadian PJT di rumah sakit Sardjito Yogyakarta.

Metode: Rancangan penelitian adalah cross sectional study Populasi penelitian adalah pasien preeklamsia dengan janin tunggal yang lahir di RSUP DR. Sardjito Yogyakarta tahun 2013-2015. Sampel penelitian adalah pasien PEB berjumlah 135 subyek, PEB awitan dini 105 subyek, dan awitan lanjut 30 subyek. Uji chi square digunakan untuk menghitung prevalensi PJT pada PEB awitan dini dan lanjut. Stratifikasi mantel-haneszel dilakukan untuk menilai variabel perancu. Multivariat menggunakan regresi logistik.

Hasil dan Pembahasan: Subyek dengan PEB awitan dini adalah 51 subyek (48,57\%) yang mengalami PJT sedangkan awitan lanjut adalah 7 subyek (23,33\%). Subyek dengan PEB awitan dini dan preeklamsia genuine memiliki prevalensi PJT lebih tinggi RP (Cl 95\%)=2,453 (1,170-5,141) dan p=0,007. Prevalensi PJT pada PEB awitan dini, OR $(\mathrm{Cl} 95 \%)=3,257(1,244-8,530)$ dan $\mathrm{p}=0,016$; usia OR $(\mathrm{Cl} 95 \%)=0,488(0,202-1,178)$ dan $\mathrm{p}=0,111 ; \mathrm{paritas}$ OR $(\mathrm{Cl}$ $95 \%)=1,159(0,461-2,912)$ dan $\mathrm{p}=0,11$; jenis PE OR $(\mathrm{Cl} 95 \%)=0,730(0,294-1,814)$ dan $\mathrm{p}=0,498$; dan derajat proteinuria OR $(\mathrm{Cl} 95 \%)=0,955(0,464-$ $1,968)$ dan $p=0,901$.

Kesimpulan: PEB awitan dini mempunyai hubungan yang signifikan dengan PJT.

Kata kunci: PEB; PEB awitan dini; PEB awitan lanjut; PJT 


\section{PENDAHULUAN}

Angka kematian akibat komplikasi kehamilan dan persalinan di negara maju yaitu 1 dari 5000 perempuan, dimana angka ini jauh lebih rendah dibandingkan di negara berkembang, yaitu 1 dari 11 perempuan meninggal akibat komplikasi kehamilan dan persalinan. ${ }^{8}$ Insidensi preeaklampsia berkisar antara 3-5\% dari seluruh kehamilan. Insidensi pada primigravida lebih tinggi dibandingkan pada multigravida. Preeklamsia pada primigravida berisiko 10-20 kali lebih tinggi untuk terjadi pada kehamilan berikutnya. ${ }^{5}$

Preeklamsiadibedakan menjadi 2 subtipe berdasarkan waktu munculnya penyakit, yaitu preeklamsia awitan dini (early onset) yang terjadi sebelum usia kehamilan 34 minggu dan preeklamsia awitan lanjut (late onset) yang terjadi saat usia kehamilan 34 minggu atau lebih. ${ }^{1}$ Angka kejadian PEB awitan dini berkisar 5-20\% dari keseluruhan kasus preeklamsia yang berhubungan dengan neonatal morbiditas dan mortalitas, sedangkan angka kejadian PEB awitan lanjut sebesar $75-80 \%$ dari keseluruhan kasus preeklamsia yang berhubungan dengan maternal morbiditas.

Preeklamsia awitan dini dan awitan lanjut memiliki perbedaan pada penyebab dan tanda klinis yang menyertai. Insidensi bayi dengan Small for Gestational Age (SGA) lebih banyak terjadi pada preeklamsia awitan dini. Keadaan tersebut menunjukkan bahwa patologi dari kelompok preeklamsia awitan dini disebabkan lebih banyak pada kerusakan plasenta. ${ }^{2}$

Preeklamsia awitan lanjut, terjadi sebanyak $80 \%$ dari seluruh kejadian preeklamsia tetapi memiliki gambaran klinis yang lebih ringan, dengan gambaran klinis adanya pertumbuhan janin yang normal tanpa disertai dengan tanda pertumbuhan janin terhambat, gambaran normal atau hanya sedikit perubahan pada arteri spiralis uterus (tidak ada perubahan dalam bentuk gelombang doppler dan tidak terdapatnya perubahan aliran darah pada arteri umbilical.

Berdasarkan data Riskesdas 2007, pertumbuhan janin terhambat (PJT) adalah salah satu komplikasi yang merupakan masalah yang paling banyak diperhatikan, meskipun antara pertumbuhan janin terhambat dan preeklamsia masih kontroversi, insidensi bayi yang kecil untuk masa kelahamilan cukup tinggi, berkisar $15-50 \%$. Sekitar dua per tiga pertumbuhan janin terhambat (PJT) berasal dari kelompok kehamilan yang berisiko tinggi, misalnya hipertensi, perdarahan antepartum, penderita penyakit jantung, dan kehamilan multipel sedangkan sepertiga lainnya berasal dari kelompok kehamilan tidak mempunyai risiko. Angka mortalitas PJT meningkat 3-8 kali dibandingkan dengan bayi dengan berat lahir normal. ${ }^{3}$

Pada kehamilan dengan preeklamsia berat memiliki hubungan terhadap PJT atau IUGR (Intrauterine Growth Restriction) $<10 \%$. Wanita hamil preeklamsia dengan riwayat hipertensi sebelumnya memiliki hubungan yang signifikan dengan kejadian IUGR $<10 \%$ dengan nilai $p$-value 0,04). Kehamilan dengan preeklamsia memiliki hubungan yang signifikan dengan IUGR3.4.

\section{METODE}

Penelitian ini adalah penelitian deskriptif analitik dengan rancangan cross sectional study. Populasi pada penelian ini adalah semua pasien dengan preeklamsia di RSUP Dr. Sardjito dari tahun 2013 sampai dengan 2015. Subyek penelitian ini adalah pasien yang di didiagnosis dengan preeklamsia berat yang sesuai dengan kriteria inklusi. Penelitian ini mengambil subyek dari Rekam Medis pasien yang pernah dirawat di RSUP Dr Sardjito Yogyakarta dari tahun 2013 sampai dengan 2015. Kriteria inklusi adalah semua ibu dengan preeklamsia berat yang mengalami kejadian pertumbuhan janin terhambat 
di RSUP Dr Sardjito tahun 2013 sampai dengan 2015. Sedangkan kriteria eksklusi adalah preeklamsia dengan komplikasi pada ibu yang bukan akibat langsung dari penyakit preeklamsia (seperti kelainan jantung, asma, penyakit infeksi kronis, anemia), Intrauterine Fetal Death (IUFD), kelainan kongenital, kehamilan kembar.

\section{HASIL DAN PEMBAHASAN}

Subjek penelitian ini sebanyak 135. Dari 135 pasien atau subyek sebagai sampel penelitian, terdapat 105 subyek dengan preeklamsia berat awitan dini dan 30 subyek dengan preeklamsia berat awitan lanjut.

Tabel 1. Karakteristik Sampel Penelitian

\begin{tabular}{|c|c|c|c|c|}
\hline \multirow{2}{*}{ Variabel } & \multicolumn{2}{|c|}{ Preeklamsia Berat } & \multirow{2}{*}{ Jumlah } & \multirow{2}{*}{$\%$} \\
\hline & Dini ( $N=105)$ & Lanjut ( $N=30)$ & & \\
\hline \multicolumn{5}{|l|}{ Usia } \\
\hline$>30$ tahun & 63 & 20 & 83 & 61,48 \\
\hline$\leq 30$ tahun & 42 & 10 & 52 & 38,52 \\
\hline \multicolumn{5}{|l|}{ Paritas } \\
\hline Primigravida & 38 & 9 & 47 & 34,81 \\
\hline Multigravida & 67 & 21 & 88 & 65,19 \\
\hline \multicolumn{5}{|l|}{ IMT } \\
\hline$\geq 27 \mathrm{~kg} / \mathrm{m}^{2}$ & 61 & 19 & 80 & 37,78 \\
\hline$<27 \mathrm{~kg} / \mathrm{m}^{2}$ & 44 & 11 & 55 & 62,22 \\
\hline \multicolumn{5}{|l|}{ Jenis PE } \\
\hline Superimposed & 27 & 2 & 28 & 20,74 \\
\hline Genuine & 78 & 28 & 107 & 79,26 \\
\hline \multicolumn{5}{|l|}{ Proteinuria } \\
\hline$\geq+3$ & \multirow{2}{*}{55} & \multirow{2}{*}{12} & 67 & 49,63 \\
\hline$<+3$ & & & 50 & 18 \\
\hline \multicolumn{5}{|l|}{ HELLP } \\
\hline Ya & 11 & 2 & 13 & 9,63 \\
\hline Tidak & 94 & 28 & 122 & 90,37 \\
\hline \multicolumn{5}{|l|}{ Sosio-ekonomi } \\
\hline Kelas III & 72 & 22 & 94 & 69,63 \\
\hline Non Kelas III & 33 & 8 & 41 & 30,37 \\
\hline
\end{tabular}

Tabel 1 menunjukkan karakteristik sampel penelitian dengan subyek penelitian keseluruhan berjumlah 135 subyek dengan rerata usia 31 tahun, usia terendah 15 tahun sedangkan usia tertinggi adalah 44 tahun. Rerata IMT adalah $29,81 \mathrm{~kg} /$ $\mathrm{m}^{2}$ dengan IMT terendah $17,60 \mathrm{~kg} / \mathrm{m}^{2}$ dan yang tertinggi adalah $66,21 \mathrm{~kg} / \mathrm{m}^{2}$. 
Tabel 2. Analisa Bivariat Hubungan antara Preeklamsia Berat dengan Pertumbuhan Janin Terhambat (PJT)

\begin{tabular}{cccccccc}
\multirow{2}{*}{ PEB } & \multicolumn{9}{c}{ PJT } & p value & RP & Cl 95\% \\
\cline { 2 - 6 } Awitan Dini & Ya (N=58) & $\%$ & Tidak (N=77) & Total & & $1,057-$ \\
Awitan Lanjut & 7 & 48,57 & 54 & 105 & 0,014 & 2,082 & 4,100 \\
\hline
\end{tabular}

Tabel 2 menunjukkan hasil analisa dengan uji Chi-Square, nilai $p=0,014$ dan Rasio Prevalensi $(\mathrm{RP}=2,082), \mathrm{Cl} 95 \%=1,057-4,100$. Nilai tersebut menunjukkan bahwa prevalensi PJT pada ibu hamil dengan PEB awitan dini tidak sama dengan prevalensi
PJT pada PEB awitan lanjut, di mana prevalensi PJT pada PEB awitan dini lebih tinggi dari pada PJT pada PEB awitan lanjut. Ibu hamil dengan PEB awitan dini beresiko mengalami PJT sebesar 2,082 dibandingkan dengan ibu hamil dengan PEB awitan lanjut.

Tabel 3. Analisis Bivariat Hubungan antara Variabel Luar dengan Pertumbuhan Janin Terhambat (PJT)

\begin{tabular}{|c|c|c|c|c|c|c|}
\hline \multirow{2}{*}{ Variabel } & \multicolumn{3}{|c|}{ PJT } & \multirow{2}{*}{ P value } & \multirow{2}{*}{$\mathbf{R P}$} & \multirow{2}{*}{$95 \% \mathrm{Cl}$} \\
\hline & $\mathrm{Ya}(\mathrm{N}=58)$ & $\%$ & Tidak (N=77) & & & \\
\hline \multicolumn{7}{|l|}{ Usia } \\
\hline$>30$ tahun & 29 & 34,94 & 54 & 0,017 & 0,627 & $0,428-0,917$ \\
\hline$\leq 30$ tahun & 29 & 55,77 & 23 & & & \\
\hline \multicolumn{7}{|l|}{ Paritas } \\
\hline Primigravida & 25 & 53,19 & 22 & 0,079 & 1,418 & $0,970-2,075$ \\
\hline Multigravida & 33 & 37,50 & 55 & & & \\
\hline \multicolumn{7}{|l|}{ IMT } \\
\hline$\geq 27 \mathrm{~kg} / \mathrm{m}^{2}$ & 32 & 40,00 & 48 & 0,402 & 0,846 & $0,574-1,246$ \\
\hline$<27 \mathrm{~kg} / \mathrm{m}^{2}$ & 26 & 47,27 & 29 & & & \\
\hline \multicolumn{7}{|l|}{ Jenis PE } \\
\hline Superimposed & 11 & 37,93 & 18 & 0,537 & 0,855 & $0,513-1,428$ \\
\hline Genuine & 47 & 44,34 & 59 & & & \\
\hline \multicolumn{7}{|l|}{ Proteinuria } \\
\hline$\geq+3$ & 29 & 43,28 & 38 & 0,940 & 1,015 & $0,688-1,497$ \\
\hline$<+3$ & 29 & 42,65 & 39 & & & \\
\hline \multicolumn{7}{|l|}{ HELLP } \\
\hline Ya & 7 & 53,85 & 6 & 0,404 & 1,288 & $0,747-2,222$ \\
\hline Tidak & 51 & 41,80 & 71 & & & \\
\hline \multicolumn{7}{|l|}{ Sosio-ekonomi } \\
\hline Kelas III & 39 & 41,49 & 55 & 0,600 & 0,895 & $0,596-1,346$ \\
\hline Non Kelas III & 19 & 46,34 & 22 & & & \\
\hline
\end{tabular}

Tabel 3 Menunjukkan hasil analisa bivariat antara variabel luar yakni usia, paritas, IMT, jenis preeklamsia, derajat proteinuria, sindrom HELLP (Hemolysis, Elevated Liver enzymes, and Low Platelets), dan status sosio ekonomi dengan PJT menunjukkan hanya usia yang nilai $\mathrm{p}<0,05$ akan tetapi tidak dapat dikatakan signifikan karena nilai Cl 95\% terdapat angka satu. Oleh karena itu dapat disimpulkan bahwa keseluruhan variabel luar dari penelitian ini tidak memiliki hubungan atau pengaruh yang signifikan terhadap prevalensi PJT. 
Tabel 4. Analisa Bivariat Hubungan antara Variabel Bebas dengan Variabel Luar

\begin{tabular}{|c|c|c|c|c|c|c|c|}
\hline \multirow{2}{*}{ Variabel } & \multicolumn{3}{|c|}{ Preeklamsia Berat } & \multirow{2}{*}{ Jumlah } & \multirow{2}{*}{ P value } & \multirow{2}{*}{$\mathbf{R P}$} & \multirow{2}{*}{$95 \% \mathrm{Cl}$} \\
\hline & Dini $(N=105)$ & $\%$ & Lanjut (N=30) & & & & \\
\hline \multicolumn{8}{|l|}{ Usia } \\
\hline$>30$ tahun & 63 & 75,90 & 20 & 83 & 0,508 & 0,940 & $0,785-1,125$ \\
\hline$\leq 30$ tahun & 42 & 80,77 & 10 & 52 & & & \\
\hline \multicolumn{8}{|l|}{ Paritas } \\
\hline Primigravida & 38 & 80,85 & 9 & 47 & 0,530 & 1,062 & $0,885-1,274$ \\
\hline Multigravida & 67 & 76,14 & 21 & 88 & & & \\
\hline \multicolumn{8}{|l|}{ IMT } \\
\hline$\geq 27 \mathrm{~kg} / \mathrm{m}^{2}$ & 61 & 76,25 & 19 & 80 & 0,607 & 0,953 & $0,796-1,141$ \\
\hline$<27 \mathrm{~kg} / \mathrm{m}^{2}$ & 44 & 80,00 & 11 & 55 & & & \\
\hline \multicolumn{8}{|l|}{ Jenis PE } \\
\hline Superimposed & 27 & 93,10 & 2 & 29 & $0,025^{*}$ & 1,265 & $1,088-1,472$ \\
\hline Genuine & 78 & 73,58 & 28 & 106 & & & \\
\hline \multicolumn{8}{|l|}{ Proteinuria } \\
\hline$\geq+3$ & 55 & 82,09 & 12 & 67 & 0,232 & 1,116 & 0,931-1,338 \\
\hline$<+3$ & 50 & 73,53 & 18 & 68 & & & \\
\hline \multicolumn{8}{|l|}{ HELLP } \\
\hline Ya & 11 & 84,62 & 2 & 13 & 0,732 & 1,098 & $0,854-1,412$ \\
\hline Tidak & 94 & 77,05 & 28 & 122 & & & \\
\hline \multicolumn{8}{|l|}{ Sosio-ekonomi } \\
\hline Kelas III & 72 & 76,60 & 22 & 94 & 0,617 & 0,952 & $0,789-1,148$ \\
\hline Non Kelas III & 33 & 80,49 & 8 & 41 & & & \\
\hline
\end{tabular}

Table4 menjelaskan nilaip darihasil uji ChiSquare menunjukkan hanya variabel jenis preeklamsia saja yang nilai $\mathrm{p}<0,05$ yakni $\mathrm{p}=0,025$ yang didukung oleh nilai $\operatorname{RP}(\mathrm{Cl} 95 \%)=1,265$ (1,088-1,472). Ibu hamil dengan jenis preeklamsia superimposed beresiko sebesar 1,265 kali mengalami PEB awitan dini dibandingkan dengan ibu hamil dengan jenis preeklamsia genuine.

Tabel 5. Analisis Stratifikasi Berdasarkan Jenis Preeklamsia (PE)

\begin{tabular}{|c|c|c|c|c|c|c|}
\hline \multirow{2}{*}{ Jenis PE } & \multicolumn{2}{|c|}{ PJT } & \multirow{2}{*}{ Ya \% } & \multirow{2}{*}{ p-value } & \multirow{2}{*}{$\mathbf{R P}$} & \multirow{2}{*}{ Cl $95 \%$} \\
\hline & Ya & Tidak & & & & \\
\hline \multicolumn{7}{|c|}{ PE Superimposed } \\
\hline Awitan Dini & 10 & 17 & $37,03 \%$ & 1,000 & 0,741 & $0,170-3,224$ \\
\hline Awitan Lanjut & 1 & 1 & $50,00 \%$ & & & \\
\hline \multicolumn{7}{|l|}{ PE Genuine } \\
\hline Awitan Dini & 41 & 37 & $52,56 \%$ & 0,007 & 2,453 & $1,170-5,141$ \\
\hline Awitan Lanjut & 6 & 22 & $21,43 \%$ & & & \\
\hline
\end{tabular}

Tabel 5 merupakan analisis stratifikasi menunjukkan bahwa pada ibu hamil dengan PEB awitan dini akan lebih kecil kemungkinan mengalami PJT apabila ibu hamil tersebut dengan jenis PE superimposed $(p=1,000, R P=0,741, C l 95 \%=0,170-3,224)$. Sebaliknya ketika ibu hamil dengan PEB awitan dini dan jenis PE genuine kemungkinan mengalami PJT meningkat atau lebih besar (=0,007, RP=2,453, Cl 95\%=1,170-5,141). 
Tabel 6. Analisis Uji Regresi Logistik antara PEB awitan dini, Usia, Paritas, Jenis Preeklamsia, Proteinuria dan Pertumbuhan Janin Terhambat (PJT)

\begin{tabular}{lccc} 
Karateristik & OR & $95 \%$ Cl & p value \\
PEB & & & \\
Awitan Dini & 3,257 & $1,244-8,530$ & 0,016 \\
Awitan Lanjut & 1 & & \\
Usia & & & \\
>30 tahun & 0,488 & $0,202-1,178$ & 0,111 \\
$\quad \leq 30$ tahun & 1 & & \\
$\begin{array}{l}\text { Paritas } \\
\text { Primigravida }\end{array}$ & 1,159 & $0,461-2,912$ & 0,753 \\
Multigravida & 1 & & \\
Jenis PE & & & 0,498 \\
Superimposed & 0,730 & $0,294-1,814$ & \\
Genuine & 1 & & 0,901 \\
Proteinuria & & & \\
$\geq+3$ & 0,955 & $0,464-1,968$ & \\
$<+3$ & 1 & & \\
\hline
\end{tabular}

Tabel 6 menunjukkan hanya PEB awitan dini yang memiliki hubungan yang signifikan dengan PJT dengan nilai $\mathrm{p}=0,016$ dan OR (CI 95\%) terbesar yakni $3,257(1,244-8,530)$.

\section{Pembahasan}

Berdasarkan penelitia diatas didapatkan hasil yang signifikan bermakna $(p<0,05)$ antara PEB dan PJT, dengan nilai $p=0,014$ dan $R P(C l 95 \%)=2,082$ (1,057-4.100) dapat disimpulkan bahwa ibu hamil dengan PEB awitan dini memiliki kemungkinan mengalami PJT sebesar 2 kali dibandingkan dengan ibu hamil dengan PEB awitan lanjut. Hasil penelitian ini sejalan dengan hasil penelitian Gezginc K, dkk yang dilakukan di Turki dimana PEB mempunyai hubungan signifikan yang bermakna dengan kejadian PJT $(p<0,05)^{2}$.

Prevalensi PJT pada ibu hamil dengan PEB yang berusia $>30$ tahun sebesar $34,94 \%$ sedangkan usia $\leq 30$ tahun adalah $55,77 \%$ dengan nilai p sebesar 0,017 dan RP Cl 95\%=(0,627) $(0,428-0,917)$. Berdasarkan status paritas, prevalensi yang mengalami PJT antara primigravida $(53,19 \%)$ dan multigravida $(37,50 \%)$ secara statistik tidak menunjukkan perbedaan yang signifikan bermakna yaitu dengan nilai $\mathrm{p}=0,079$ dan RP (Cl 95\%) sebesar 1,418 (0,970-2,075). Kejadian PJT yang mana tidak menunjukkan adanya perbedaan yang bermakna antara kejadian PJT pada ibu hamil yang obesitas (40\%) dan tidak obesitas $(47,27 \%)$ dengan nilai $p=0,402$ dan RP (Cl 95\%) sebesar 0,846 (0,574-1,246).

Hasil uji Chi Square untuk ketiga variabel ini (usia, paritas, dan IMT) sejalan dengan penelitian yang dilakukan Weiler dkk, (usia $p=0,63$, paritas $p=0,27$, dan IMT $p=0,14)$. Namun penelitian yang dilakukan Srinivas dkk, memiliki hasil yang sebaliknya yakni status paritas $(p=0,001)$ dan IMT $(p=0,008)$ memiliki hubungan dengan kejadian $\mathrm{PJT}^{6.7}$.

Pada penelitian, prevalensi ibu hamil dengan derajat proteinuria secara statistik perbedaan prevalensi kedua kelompok ini tidak signifikan dengan nilai $p=0,940$ dan RP (CI 95\%) sebesar 1,015 $(0,688-1,497)$, artinya tidak terdapat perbedaan prevalensi PJT pada ibu hamil baik dengan derajat proteinuria $\geq+3$ maupun $<+3$, Hal ini sejalan dengan penelitian yang dilakukan Jane Weiler J dkk, dimana derajat proteinuria tidak berhubungan dengan PJT $(p=0,70)^{7}$.

Hasil uji Chi Square antara sindrom HELLP dan PJT adalah nilai $\mathrm{p}=0,404$ dan RP (Cl 95\%) sebesar $1,418(0,970-2,075)$. Nilai-nilai ini menunjukkan tidak adanya perbedaan prevalensi PJT yang bermakna 
antara ibu hamil dengan sindrom HELLP $(53,85 \%)$ dan ibu hamil tanpa sindrom HELLP $(41,80 \%)$.

Hasil uji biavariat antara status sosio ekonomi dan PJT menunjukkan nilai $\mathrm{p}=0,600$ dan $\mathrm{RP}(\mathrm{Cl} 95 \%)$ sebesar 0,895 (0,596-1,346), artinya perbedaan prevalensi PJT berdasarkan status sosio ekonomi ibu hamil adalah tidak bermakna signifikan. Hal ini tidak sejalan dengan penelitian yang dilakukan oleh Villar dkk, (2006) yang menunjukkan adanya hubungan antara status sosio ekonomi dengan kejadian PJT yakni dengan nilai $p<0,05$ dan OR (CI 95\%) 1,2 (1,1-1,3) 7 .

Berdasarkan hasil uji stratifikasi yang dilakukan, diketahui bahwa prevalensi PJT pada ibu hamil dengan PEB awitan dini dan jenis PE genuine (52,56\%) lebih tinggi dibandingkan jenis PE superimposed $(37,03 \%)$. Perbedaaan ini signifikan dengan nilai $\mathrm{p}=0,016$. Kesimpulannya adalah prevalensi PJT meningkat ketika ibu hamil dengan PEB awitan dini memiliki jenis $P E$ genuine.

Analisis mutivariat dengan Regresi Logistik untuk menilai hubungan dari kelima variabel secara bersamaan atau spontan terhadap PJT. Hasil analisis ini menunjukkan adanya hubungan yang kuat atau signifikan bermakna baik secara statistik maupun klinis antara PEB awitan dini dan PJT dengan nilai $\mathrm{p}=0,016$ dan OR $(\mathrm{Cl} 95 \%)=3,257(1,244-8,530)$. PEB awitan dini menjadi faktor risiko terjadinya PJT, dimana pasien dengan PEB awitan dini berisiko sebesar 3,2 kali mengalami PJT dibandingkan dengan pasien PEB awitan lanjut.

\section{KESIMPULAN DAN SARAN}

Hasil penelitian ini menunjukkan bahwa PEB awitan dini berisiko sebesar 3,2 kali mengalami PJT dibandingkan dengan pasien PEB awitan lanjut, dengan nilai OR $(\mathrm{Cl} 95 \%)=3,257(1,244-8,530)$ dan $p=0,016$.

\section{DAFTAR PUSTAKA}

1. Aksornphusitaphong, A., \& Phupong, V. 2013. Risk factors of early and late onset pre-eclampsia. Journal of Obstetrics and Gynaecology Research, 39(3): 627-631

2. Gezer, C. 2015. The role of the first trimester inflammation markers at early and late preeclampsia. Perinatal Journal, 22(3): 128-132. http://doi.org/ 10.2399/prn.140223003.

3. Hartono, P. 2016. Pengelolaan Kehamilan Dengan Pertumbuhan Janin Terhambat. Perkumpulan Obstetri Dan Ginekologi Indonesia Himpunan Kedokteran Feto Maternal 2016

4. Hod, T., Cerdeira, A. S., \& Karumanchi, S. A. 2015. Molecular Mechanisms of Preeclampsia. Cold Spring Harbor Perspectives in Medicine, 5(10): a023473. http://doi.org/10.1101/cshperspect.a023473

5. Lisonkova, S., \& Joseph, K. S. 2013. Incidence of preeclampsia: Risk factors and outcomes associated with early-versus late-onset disease. American Journal of Obstetrics and Gynecology, 209(6): 544. e1-544.e12

6. Srinivas, S. K., Edlow, A. G., Neff, P. M., Sammel, M. D., Andrela, C. M., \& Elovitz, M. A. 2009. Rethinking IUGR in preeclampsia: Dependent or independent of maternal hypertension?. Journal of Perinatology, 29(10): 680-684. http://doi.org/10.1038/jp.2009.83

7. Villar, J., Carroli, G., Wojdyla, D., Abalos, E., Giordano, D., Ba'aqeel, H., Kramer, M. 2006. Preeclampsia, gestational hypertension and intrauterine growth restriction, related or independent conditions?. American Journal of Obstetrics and Gynecology, 194(4): 921-931

8. Wibowo, N., Rima, I., Edwina, F., Made Kornea, K., Johannes C., M., \& Maisuri T. 2016. Diagnosis dan Tatalaksana Pre Eklamsia. Pogi: 6-9 